UDC 94(47).081

Submitted: 27.02 .2018

LBC 63.3(2)52

Accepted: 24.05.2018

\title{
TO THE HISTORY OF PRIVATE RAILWAY CONSTRUCTION IN RUSSIA IN THE 1860-1870s
}

\author{
Elena I. Nazarova \\ Saint Petersburg State Universiy, Saint Petersburg, Russian Federation
}

\begin{abstract}
This paper is devoted to the problem of alienation of real estate for the construction of railways in Russia in the 1860-1870s, when there was the first railway 'boom' in the country. The process of transferring real estate from private ownership to the railway companies caused a number of difficulties not only in Russia but also in the majority of European countries, which constructed railways in the $19^{\text {th }}$ century. Despite the extensive historiography of the rail transport, the issue of the alienation of private lands remains insufficiently studied. This research contains the results of complex analysis of the Russian legislation of the indicated period, devoted to the right to real estate and regulating the process of lands alienation for the state needs. The analysis of legislation let revealing the legal framework of alienation of state and private lands, as well as the peculiarities of peasants' property alienation process. It is shown that despite the government's attempts to regulate the process, it was often accompanied by conflicts between railway companies and the real estate owners. We consider the specific examples of real estate alienation from people of different social classes.

The Russian government tried to restore order in the process of real estate alienation for the railway construction. Nevertheless, the process was characterized by a number of disadvantages: the administrative procedure for real estate alienation; indefinite terms for payment of compensation to proprietors; unclear wording in the law. All this led to the fact that the process of property valuation had been sometimes delayed for decades.

Key words: railway, private railway company, expropriation of real estate, alienation of land, disposition of property.

Citation. Nazarova E.I. To the History of Private Railway Construction in Russia in the 1860-1870s. Vestnik Volgogradskogo gosudarstvennogo universiteta. Seriya 4, Istoriya. Regionovedenie. Mezhdunarodnye otnosheniya [Science Journal of Volgograd State University. History. Area Studies. International Relations], 2018, vol. 23, no. 4, pp. 51-61. (in Russian). DOI: https://doi.org/10.15688/jvolsu4.2018.4.6
\end{abstract}

УДК 94(47).081

ББК $63.3(2) 52$

Дата поступления статьи: 27.02.2018

Дата принятия статьи: 24.05.2018

\section{К ИСТОРИИ ЧАСТНОГО ЖЕЛЕЗНОДОРОЖНОГО СТРОИТЕЛЬСТВА В РОССИИ В 60-70-е ГОДЫ ХІХ ВЕКА}

\author{
Елена Игоревна Назарова \\ Санкт-Петербургский государственный университет, г. Санкт-Петербург, Российская Федерация
}

\begin{abstract}
Аннотация. Данная статья посвящена проблеме отчуждения недвижимости под строительство железных дорог в России в 60-70-е гг. ХІХ столетия, когда в стране наблюдался первый железнодорожный «бум». Процесс отвода собственности из частного владения в пользу железнодорожных компаний порождал ряд $\infty$ сложностей, которые были присущи не только России, но и большинству европейских государств, сооружавших рельсовые дороги в XIX веке. Несмотря на обширную историографию железнодорожного транспорта, вопрос отвода частной собственности остается недостаточно изученным. В процессе исследования был проведен комплексный анализ российского законодательства указанного периода, посвященного праву частной собственности и регулирующего процесс отвода имущества для государственных нужд. В ходе анализа законодательства была раскрыта правовая основа изъятия государственных и частных земель, выявлены особенности порядка отвода собственности у крестьян. Показано, что, несмотря на попытки правительства урегулировать процесс, отчуждение собственности нередко сопровождалось конфликтами между железно-
\end{abstract}


дорожными компаниями и владельцами недвижимости. Рассмотрены конкретные примеры отвода земель под железные дороги из собственности людей разных сословий.

Российское правительство пыталось навести порядок в процессе отчуждения частной собственности под строительство железных дорог. Тем не менее оно содержало ряд минусов: административный порядок отвода земель, неопределенные сроки выплаты компенсации собственникам, нечеткие формулировки в законе. Все это приводило к тому, что процесс оценки имущества затягивался иногда на десятилетия.

Ключевые слова: железная дорога, частная железнодорожная компания, реквизиция недвижимости, отчуждение земель, отвод собственности.

Цитирование. Назарова Е. И. К истории частногожелезнодорожного строительства в России в 60-70-е годы XIX века // Вестник Волгоградского государственного университета. Серия 4, История. Регионоведение. Международные отношения. - 2018. - Т. 23, № 4. - C. 51-61. - DOI: https://doi.org/10.15688/jvolsu4.2018.4.6

Введение. В ХІХ столетии в Европе и США железные дороги стремительно набирали популярность как удобный, быстрый и относительно дешевый вид транспорта, олицетворявший собой технический прогресс. Однако практически повсеместно их сооружение породило ряд проблем, связанных, помимо прочего, с необходимостью отвода земель под строительство железнодорожных линий. О том, как такие проблемы решались в России в 60-70-е гг. XIX в. и пойдет речь в настоящей статье.

Методы. Историография железных дорог в России весьма велика и разнообразна. Дореволюционные и советские историки преимущественно рассматривали технические и экономические вопросы развития железнодорожной отрасли (открытие первых железных дорог, создание паровозного парка, рентабельность эксплуатации железных дорог частными компаниями). В исследованиях подчеркивались негативные явления, связанные с формированием железнодорожной сети в России, а именно: коррупция среди чиновников, казнокрадство и неудовлетворительное качество сооружавшихся линий. Наиболее полно данные вопросы освещены в трудах Н.А. Кислинского [9], А.М. Соловьевой [24], А.П. Погребинского [20] и И.Ф. Гиндина [5]. Современные исследователи, с одной стороны, продолжают изучать проблемы, обозначенные в предыдущие периоды, а с другой - стараются рассматривать историю железных дорог в новом ракурсе. Появляются работы, исследующие повседневную жизнь служащих русских железных дорог, воздействие железнодорожных магистралей на экономику регионов, по территории которых они пролегали. Например, это работы О.О. Непоспехова [11], А.В. Лу- ночкина [10], А. Вульфова [1]. В 2009 г. вышло крупное исследование Л.В. Галактионовой [3], посвященное эволюции имущественных отношений на железнодорожном транспорте в Российской империи. Автор, проведя комплексный историко-правовой анализ, пришла к выводу, что земли, занятые с середины 60-х гг. под железные дороги продолжали составлять государственную собственность. В своей работе Л.В. Галактионова сконцентрировала внимание преимущественно на юридических вопросах процесса отвода земли. В то же время остается мало изученной степень превращения юридической нормы в обыденную практику отчуждения недвижимости у частных собственников под строительство железных дорог.

В ходе рассмотрения эволюции процедуры отчуждения собственности в 60-70-е гг. XIX столетия был проведен сравнительный анализ законодательства, посвященного данному вопросу, выделены доминирующие тенденции. На основе обширного архивного материала, хранящегося в Российском Государственном историческом архиве (РГИА), удалось не только выявить факты организации отвода земель на практике для разных категорий населения, но и сравнить их с действующим законодательством. Данный метод позволил раскрыть сущность проблемы отчуждения собственности в целом, а также конкретно для железнодорожного транспорта.

В исследовании были широко использованы законодательные и нормативные акты, помещенные в Полном Собрании Законов Российской империи и Своде законов 1857 г., отражающие правительственную политику по отношению к отчуждению собственности. Другим блоком источников стали делопроиз- 
водственные материалы из фонда Канцелярии министра путей сообщения, находящиеся в РГИА: переписка между учреждениями, справки и отчеты инспекторов частных железных дорог, оценочные документы, позволяющие реконструировать процесс отвода земель на практике.

Анализ. В 60-70-е гг. XIX столетия в России правительство массово поощряло частную инициативу при сооружении железнодорожных линий, оно охотно выдавало концессии и даже гарантировало прибыль по акциям частных железнодорожных обществ. Но в то же время государство во многом было не готово к такому широкомасштабному развитию железнодорожной отрасли. В стране отсутствовали заводы, которые могли бы в достаточном объеме производить паровозы и рельсы, не хватало квалифицированных кадров, обслуживающих машины. Кроме того, отсутствовала нормативная база, позволяющая регулировать взаимоотношения государства и частных железнодорожных компаний, а также регламентировать строительство и эксплуатацию железных дорог в России. Все эти вопросы государству приходилось решать непосредственно в процессе сооружения сети железных дорог. Одной из главных задач правительства с конца 50-х по 70-е гг. было создание специальных правил о принудительном отчуждении недвижимости для нужд железной дороги [3, с. 151].

Как в сущности уже отмечалось, Россия не была единственной страной столкнувшейся с такого рода проблемой. Например, в Великобритании право частной собственности традиционно считалось незыблемым. Однако в XIX в. с началом железнодорожного строительства власти должны были решать непростую задачу - защищать и права землевладельцев, и интересы владельцев железных дорог. Земельный фонд в Великобритании был невелик, земля стоила дорого, некоторые недобросовестные учредители железных дорог стали спекулировать земельными участками, отданными им в распоряжение. Многие предприниматели рассчитывали получить право на строительство железной дороги, чтобы потом перепродать его тому, кто предложит большую цену или распродать земли, полученные в собственность путем рек- визиции у первоначальных владельцев. В таких случаях коммерсанты вовсе не ставили перед собой цель построить железную дорогу. Английскому парламенту пришлось создавать механизмы защиты интересов частных собственников и разрабатывать четкий порядок отчуждения земель для строительства железных дорог. В Англии, чтобы пресечь спекуляции с недвижимостью, земля переходила в собственность железнодорожных компаний только после того, как железная дорога была построена и введена в эксплуатацию [8, c. 250-261].

В Российской империи вопрос о правомерности реквизиции частной собственности в пользу государства впервые поднимается в правление Екатерины II [4]. До этого момента это право государства не подлежало сомнению. На протяжении первой половины XIX в. эта проблема остается предметом дискуссии в правительственных кругах, но тем не менее к середине века вырабатывается порядок отвода земель из частного владения. Случаев, когда государство прибегало к этой мере, было немного, в основном им пользовались при строительстве новых шоссе или для военных нужд. Однако во второй половине $50-\mathrm{x}$ гг. ситуация меняется: правительство задается целью создать разветвленную сеть железных дорог, столь необходимых стране. Для решения этой задачи в 1857 г. было образовано Главное общество российских железных дорог (далее ГОРЖД), которому было поручено построить сразу три новых линии. С этого момента количество случаев отчуждения собственности резко возрастает [21, с. 313-315].

Право железнодорожных компаний занимать частные земли и здания было официально закреплено в Уставе Царскосельской железной дороги [2]. В уставах периода 60-70-х гг. это право подтверждалось. Относительно просто решалась ситуация с передачей казенных земель в собственность железнодорожных обществ. Свободные (невозделанные и не составляющие оброчных статей) государственные земли безвозмездно предоставлялись в распоряжение частным компаниям. В то же время земли, приносящие доход казне, железнодорожным обществам приходилось выкупать. В 1859 г. Министерство государственных имуществ 


\section{ОТЕЧЕСТВЕННАЯ ИСТОРИЯ}

составило особую инструкцию с правилами оценки казенных земель, согласно которой оценку стоимости недвижимости проводили специально командированные чиновники данного ведомства. В итоге стоимость государственных земель оказывалась существенно завышенной по сравнению со стоимостью земель частных владельцев, что приводило к возражениям со стороны железнодорожных обществ [17]. Это положение изменилось только после принятия в 1868 г. новой инструкции для отвода и оценки казенных земель, по которой порядок оценки стоимости частного имущества стал распространяться на государственную недвижимость [15].

С юридической точки зрения урегулирование вопроса об отчуждении частной собственности было более сложным процессом. Земли и иное имущество, принадлежащие частным лицам, отчуждались только с санкции императора. Полное собрание законов Российской империи содержит множество именных указов, разрешающих передачу собственности в пользу конкретного железнодорожного общества. Причем компания должна была самостоятельно договориться с владельцем о сумме выкупа недвижимости. Если прийти к соглашению сторонам не удавалось, то вступали в силу правила отчуждения частной собственности.

К моменту учреждения ГОРЖД (одной из первых частных железнодорожных компаний) в 1857 г. уже были разработаны общие правила передачи собственности в пользу государства [12, ст. 575-593]. После того, как был подготовлен план сооружения дороги и получено дозволение императора, местные органы власти связывались с владельцами недвижимости, предоставляли им проекты сооружения железнодорожных линий, делали запрос о цене, за которую владелец готов был продать свою собственность $[12$, ст. 577]. Если собственник и лицо, в пользу которого отчуждалось имущество, договориться не могли, то независимая комиссия должна была произвести оценку имущества $[12$, ст. 582]. Ее состав зависел от местности, в которой располагалась недвижимость, и от сословной принадлежности владельцев собственности. Если недвижимость принадлежала купцу, разночинцу или мещанину, то имущество оценивал городской голова, а если владельцем был дворянин, то в комиссию включался уездный предводитель дворянства. В состав комиссии дополнительно входил инженер - губернский архитектор, техник по назначению правления местного округа путей сообщения, губернский или уездный землемер. В уездах оценку производили владельцы близко расположенных подобных имуществ. Если имущество приобреталось для Главного управления путей сообщений и публичных зданий (далее ГУПСиПЗ), то при оценивании должен был находиться представитель этого ведомства [12, ст. 583].

Оценка имущества делалась в присутствии владельца, его управляющего или поверенного и местной полиции. По окончании собственнику выдавался письменный документ с описью недвижимости. Если владелец был несогласен с решением оценочной комиссии, то в течение следующих восьми дней он или его поверенный могли подать в письменной форме свой протест [12, ст. 585-586]. После завершения оценки, комиссия направляла дело в то министерство, от которого оно поступило. Если оценка производилась в уезде или уездном городе, то к оценке прилагалось мнение губернатора [12, ст. 588]. Решение комиссии было окончательным и пересмотру не подлежало. Однако закон требовал дать собственнику приличное (что является приличным - не уточнялось) вознаграждение за потерянное имущество [12, ст. 575]. Ему предоставлялся выбор - получить денежное вознаграждение или новый земельный участок в другом месте. Вся сложность заключалась в верной оценке имущества. При оценивании земельных участков обязательно учитывалось качество и назначение земельных угодий, доход, получаемый владельцем с недвижимости, потерянная им выгода или упущенная возможность. Например, если отчуждалась изба, в которой находилось питейное заведение, то должен был учитываться доход, который получал владелец от его содержания. Дополнительная плата полагалась за снос строений, например, домов и хозяйственных построек. Предусматривался перенос их на новое место за государственный счет или на средства организации, в пользу которого отчуждалась земля под постройками [12, ст. 584]. 
В то же время размер компенсации владельцам за потерянное имущество мог быть увеличен до 1/5 части от суммы, предназначенной им по решению оценочной комиссии. Условия доплаты были следующие: владелец должен был согласиться с решением оценочной комиссии. Как правило, размер компенсации вместе с добавочной стоимостью был существенно меньше той суммы, за которую собственник первоначально желал продать свое имущество [12, ст. 590-591].

Между тем, бывали случаи, когда определить доход с имущества было весьма затруднительно или совсем невозможно. Тогда оценочные комиссии определяли среднее число дохода [18]. Это была сумма чистого дохода с недвижимости за 10 лет, разделенная на 10 равных частей [18, ст. 1976-1977]. Далее среднее число умножалось на коэффициент, рассчитанный для разного рода имущества, а получившаяся в итоге сумма признавалась стоимостью объекта. Например, при оценке недвижимости населенных пунктов среднее число дохода умножалась на 10 . Таким образом, цена имущества равнялась сумме чистого дохода за 10 лет. Чтобы получить стоимость каменного строения, нужно было умножить средний доход на 8 , деревянного на 6 [18, ст. 1979, 1981, 1982]. На таком же основании производился расчет ненаселенных земель - пашен, лугов, сенокосов, пустошей, огородов. Здесь за основу бралась сумма годового дохода, получаемого с недвижимого имущества [18, ст. 1980]. В случае если рассчитать его было нельзя, то оценка производилась по местным обстоятельствам [18, ст. 1985]. Что считалось местными обстоятельствами - не конкретизировалось. Эта неопределенная формулировка в тексте закона приводила к тому, что собственники имущества писали жалобы в ГУПСиПЗ, и оценочным комиссиям приходилось несколько раз проводить повторные переоценки земель, что, в свою очередь, увеличивало сроки процедуры передачи собственности.

Заключительным этапом процесса отчуждения было подписание купчей крепости на владение землей. Но, как правило, владелец не мог сразу получить деньги на руки. Этому способствовали бюрократические проволочки. Если сумма компенсации была менее 3000 руб., то дело заканчивалось решением министров или других высших должностных лиц [12, ст. 589]. Дела о выплате сумм, размером от 3000 и более первоначально рассматривались в Государственном совете, а затем поступали на высочайшее рассмотрение.

В Российской империи часть земельного фонда находилась в собственности церкви. На церковные владения распространялись такие же правила реквизиции, как и на имущество частных лиц. [12, ст. 593].

Этот механизм был универсальными для всех случаев, когда государству требовалось изъять собственность, например, для прокладки шоссе. Однако при строительстве железных дорог существовали некоторые особенности. Фактически государство передавало земли в распоряжение частных компаний. Отсюда с собственниками о размере компенсации первоначально договаривались агенты, делегированные от железнодорожных обществ. Губернатор формально не мог вмешиваться в процесс изъятия недвижимости, однако он отчитывался перед Министерством путей сообщения о ходе отчуждения и подавал в письменной форме свое мнение о результатах деятельности оценочных комиссий. К нему обращались как собственники, так и правление железной дороги, чтобы ускорить процесс разрешения дела. Деньги, присужденные владельцам по решению оценочной комиссии, компания вносила в уездное казначейство на счет оценочной комиссии, и только потом они могли быть выданы собственникам. Кроме того, при строительстве шоссе бывшие владельцы земельных участков получали право безвозмездно ездить по новой дороге. Частные железнодорожные общества, заинтересованные в прибыли, уже не могли позволить собственникам бесплатно пользоваться услугами их компании.

Отмена крепостного права повлекла за собой внесение поправок в порядок отчуждения собственности. Согласно положению Главного Комитета об устройстве сельского состояния от 18 января 1862 г. помещик не был обязан, но мог по желанию выделить крестьянам новые участки земли взамен отошедших под железную дорогу. Кроме того, он не имел права требовать уменьшения надела 


\section{ОТЕЧЕСТВЕННАЯ ИСТОРИЯ}

крестьян, если земля до момента отчуждения находилась в его распоряжении. Помещик был обязан договориться с крестьянами об уменьшении повинностей, определенных в уставной грамоте. Также на него ложились расходы по переносу крестьянских строений, расположенных на территории, отходящей в пользу железнодорожной компании. Если помещик и крестьяне не могли договориться о размере расходов, сопряженных с потерей имущества, и размере снимаемых с крестьян повинностей, то в дело вступал мировой посредник. Он в присутствии помещика, уполномоченного от крестьян и «посторонних сведущих добросовестных людей» (что это были за люди, в законе не уточнялось) проводил оценку размера слагаемых повинностей и расходов крестьян. Стороны, недовольные решением, могли обжаловать его, обратившись к мировому съезду, а если заключение последнего вновь их не устраивало, то конфликт рассматривало Губернское по крестьянским делам присутствие, вердикт которого уже был окончательным [22].

В конце 60-х гг. правительство приняло ряд специальных законов, посвященных отводу земель, принадлежащих бывшим государственным и помещичьим крестьянам. После отмены крепостного права приходилось учитывать изменившееся положение крестьян; отсюда непростой порядок выплаты компенсации и усложнившийся способ ее расчета. Согласно Положению Главного комитета об устройстве сельского состояния от 5 мая 1867 г. купчая крепость подписывалась в установленном, общем порядке в случае, если крестьяне выкупили свой надел, то есть стали полноправными собственниками. В соответствии со статьями 161 и 169 высочайше утвержденного «Положения о выкупе крестьянами, вышедшей из крепостной зависимости, их усадебной оседлости, и содействии правительства к приобретению семи крестьянами в собственность полевых угодий» крестьяне в течение следующих 9 лет со дня издания указа не могли продавать свои наделы [23]. Однако с 1867 г. эти статьи не действовали в отношении отвода земель под железнодорожные линии. Купчие крепости за земли, приобретенные крестьянами с содействием правительства, до уплаты выкупной ссуды обяза- тельно регистрировались в Губернском по крестьянским делам присутствии. А сумма денежной компенсации за утраченную собственность отсылалась в местное казначейство в качестве уплаты выкупной ссуды [13]. Фактически, благодаря этому положению, крестьяне могли не получить никакой компенсации за утерянное имущество. 31 октября 1868 г. вышло новое положение, которое касалось отчуждения земель, находящихся в составе надела бывших государственных крестьян в пользу железнодорожных обществ. Документ еще раз подтверждал, что размер вознаграждения крестьян, выкупивших свои участки в собственность, определялся по общему правилу, распространявшемуся на всех частных владельцев. В противном случае (это касалось большинства крестьян) 3 часть денежной компенсации отходила в пользу государственной казны. В то же время уменьшался размер оброчной подати или выкупных платежей, лежащих на крестьянах, в размере 5 коп. с каждого рубля вознаграждения, обращенного в пользу государства. В случаях, когда официальная купчая крепость еще не была подписана, а некоторые домохозяева уже лишись большей части своих участков, то им, по возможности, должны были предложить новые земли взамен потерянных участков. При подписании купчей крепости, как и в предыдущем случае, необходимо было известить местное Губернское по крестьянским делам присутствие об изменении владельцев [16].

Из перечисленных выше правил видно, что государство защищало интересы собственников, а процесс отвода земель требовал большого количества времени, поэтому разрешение разногласий между владельцами и правлением железнодорожных обществами иногда затягивались на годы. В то же время железнодорожные компании имели ограниченные сроки для выполнения строительных работ, чаще всего они должны были построить железную дорогу в течение 2-3 лет с момента принятия устава и образования акционерного общества. Пик выдачи железнодорожных концессий приходится на период с 1868 по 1872 год. В этих условиях для ускорения процедуры передачи собственности в 1872 г. Комитет министров ввел временные правила, 
по которым устанавливался двухнедельный срок для проведения описи имущества собственников [19]. Общество железной дороги составляло план отчуждения имуществ, которое затем предоставлялось губернатору для распоряжения об оценки имуществ. Опись недвижимости проводил член городской или земской полиции. Затем имущество переходило в собственность железнодорожной компании, а все претензии по отчуждению рассматривала оценочная комиссия. Если каких-либо документов на собственность не хватало во время проведения описи, то они доставлялись позже уже в оценочную комиссию. Все издержки по проведению процесса отчуждения несла на себе железнодорожная компания. Временные правила ежегодно продлевались вплоть до 1881 г., когда новым положением Комитета министров по рапорту министра путей сообщения срок действия временных правил продолжался «до издания на новых по сему предмету законоположений» [14].

На практике главная проблема при отчуждении земель создавалась в ходе переговоров о цене между представителями частных железнодорожных компаний и собственниками. Складывалась классическая ситуация, когда владельцы желали продать свою собственность как можно дороже и искали любой предлог для повышения ее стоимости, а агенты компаний старались сбить расценки и купить по умеренным ценам. Эта ситуация приводила к тому, что, как правило, стороны не могли договориться с первого раза о размере компенсации.

Если собственники и правление железнодорожной компании не могли прийти к компромиссу о размере компенсации, первые часто обращались с письменными прошениями к губернаторам или министру путей сообщения с просьбой помочь разобраться в деле. В 1868 г. при строительстве Московско-Орловской железной дороги владелец имения в Орловской губернии И.П. Шаблыкин подал прошение на имя губернатора с просьбой разобраться в деле с оценкой его имущества, в ходе которой агенты железной дороги нарушили регламент и не предоставили ему в восьмидневный срок официального документа с точной оценкой его имущества. Больше всего И.П. Шаблыкина огорчил размер при- читающегося ему вознаграждения, за 1 десятину его земельных угодий давали 50 руб. серебром. Губернатор и оценочная комиссия посчитали такую сумму справедливой, сославшись на то, что согласно положению от 19 февраля 1861 г. земли Орловской губернии оценивались по 50 руб. серебром за 1 десятину [7]. Таким образом, фактически земля была оценена не по рыночной стоимости на 1868 г., а по устаревшей, зафиксированной на 1861 год.

Крестьяне не отставали от дворян и тоже старались получить максимум выгоды от потери своего имущества. В 1870 г. под строительство Московско-Смоленской железной дороги отчуждались земельные угодья, принадлежавшие собственникам деревни Лаги в Смоленской губернии. Всего 6 десятин 684 кв. саженей разнородной земли. Первоначально крестьяне требовали заплатить им 13380 руб. 60 коп. Эта сумма рассчитывалась из стоимости 6,7 десятин разнородной земли, работ по строительству изгороди вдоль железнодорожного полотна, стоимости переноса строений 3 домовладельцев из полосы отчуждения, а также компенсации за неиспользованные в течение 3 лет земельные угодья, отошедшие под железную дорогу. Естественно, что правления железной дороги не могло согласиться с такой суммой. Тогда была созвана оценочная комиссия, которая присудила 654 руб. 90 коп. за все (в том числе за изгородь и ущерб). Крестьяне посчитали сумму слишком маленькой и подали протест на решение комиссии в установленный восьмидневный срок. Также они написали жалобу в МПС с просьбой переоценить землю. В янваpe 1871 г. МПС распорядилось провести повторную переоценку, но из-за бюрократических проволочек оно было исполнено через 8 месяцев. Новая оценочная комиссия, состоящая из помещиков, постановила выплатить крестьянам 8115 руб. за все причиненные неудобства (в том числе 3323 руб. за землю). На этот раз возмутилась железнодорожная компания. Депутат от Управления железной дороги в своих возражениях ссылался на то, что доказательства помещиков о доходности земли были голословными, а сами помещики не были соседними домовладельцами, как требовал закон. К тому же кресть- 
яне платили выкупные платежи государству, а потому по всем расчетам они должны были получить 384 руб., а с 1/5 части вознаграждения, 461 руб. 91 коп. за землю вместо 3323 руб. согласно решению оценочной комиссии. Губернатор в своем мнении не поддержал доводы депутата и присудил выплатить только 3293 руб. за землю (30 руб. вычитались в пользу оценочной комиссии за ее работу). В апреле 1872 г. Совет министра путей сообщения вторично рассмотрел и постановил, что оценка земли была проведена неверно с точки зрения законодательства. МПС назначило новую (третью по счету) переоценку недвижимости крестьян деревни Лаги. Согласно акту Духовщинской уездной комиссии о переоценке от 5 сентября 1879 г. крестьянам за потерянное имущество было присуждено 877 руб. 70 коп., из которых исключили выплаты по разного рода повинностям (еще в 1871 г. за крестьянами деревни Лаги числилась недоимка). Таким образом, крестьянам оставалось 677 руб. За перенос строений и сооружение изгороди платы не полагалось. В итоге после очередного рассмотрения дела Министерство путей сообщения постановило выплатить крестьянам 812 руб. (в сумму вошли $6 \%$ в год с каждых 100 руб. со дня занятия земель по день взноса в оценочную комиссию). На руки владельцы получили деньги только в июне 1883 г., через 14 лет после того, как их земли отошли под железную дорогу [6]. В 60-70-е гг. XIX в. аналогичных ситуаций было много.

Результаты. Подводя итоги, мы можем сделать вывод, что в 60-70-е гг. XIX в. правительство предпринимало попытки навести порядок в процессе отчуждения недвижимости под нужды железнодорожных компаний. Так, государство заметно сократило сроки, отводившиеся на эту операцию. В то же время, хотя право собственников на получение денежной компенсации за утраченное имущество сомнению не подвергалось, момент выплаты причитающейся им суммы переносился на неопределенное время. Отчуждение недвижимости проходило в административном порядке, то есть без привлечения суда. В результате ГУПСиПЗ, а потом МПС, оказались завалены жалобами на представителей компании и оценочные комиссии от владельцев зем- ли, которая должна была отойти под железнодорожные линии. Отметим, что прошения в МПС подавали именно собственники, обратные случаи, когда частная железнодорожная компания обращалась с жалобами в центральные государственные органы, не обнаружены. Зачастую расплывчатые формулировки в гражданском законодательстве не позволяли трактовать соответствующие нормативные акты однозначно. Это обстоятельство, а также отсутствие точно установленных сроков проведения процедуры отчуждения недвижимости, затягивало процесс ее оценки, что, в свою очередь, вызывало нарушение установленного законом порядка и зачастую порождало весьма острые правовые коллизии.

\section{СПИСОК ЛИТЕРАТУРЫ}

1. Вульфов, А. Б. Повседневная жизнь российских железных дорог / А. Б. Вульфов. - М. : Молодая гвардия, 2007. $-496 \mathrm{c}$.

2. Высочайше утвержденное положение об учреждении общества акционеров для сооружения железной дороги от Санкт-Петербурга до Царского села, с продолжением до Павловска. 21 марта 1836 г. // Полное собрание законов Российской империи (ПСЗРИ). Собр. 2-е. - Т. 11, ч. 1. - № 9009.

3. Галактионова, Л. В. Правовое регулирование поземельных отношений на железнодорожном транспорте в Российской империи (1836-1917) / Л. В. Галактионова. - Хабаровск : Изд-во Дальневосточ. гос. ун-та путей сообщения, 2009. - 151 с.

4. Генерал-прокурорский наказ при комиссии о составлении проекта нового Уложения, по которому и маршалу поступать. 30 июля 1767 г. // ПСЗРИ. Собр. 1-е. - T. 18. - № 12950.

5. Гиндин, И. Ф. Государственный банк и экономическая политика царского правительства (1861-1892) / И. Ф. Гиндин. -М. : Госфиниздат, 1960. $-415 \mathrm{c}$.

6. Дело о вознаграждении крестьян, собственников деревни Лаги за землю, отошедшую под Московско-Смоленскую железную дорогу. 12 декабря 1970 по 16 декабря 1883 года // Российский государственный исторический архив (РГИА). - Ф. 229.Оп. 7. - Д. 4. -111 л.

7. Дело о вознаграждении статского советника Шаблыкина и гг. Ананьевских за земли, отчуждаемые под Орловско-Московскую железную дорогу. 1868-1884 гг. // РГИА. - Ф. 229. -Оп. 7. -Д. 1. 51 л.

8. Доббин, Ф. Формирование промышленной политики: Соединенные штаты Америки, Великоб- 
ритания и Франция в период становления железнодорожной отрасли / Ф. Доббин. - М. : Изд. дом Высшей школы экономики, 2013. - 368 с.

9. Кислинский, Н. А. Наша железнодорожная политика по документам Комитета Министров / Н. А. Кислинский. - СПб. : Издание канцелярии Комитета министров, 1902. - Т. 1.-324 с.

10. Луночкин, А. В. Проблема отчуждения земли при строительстве Волго-Донской железной дороги (1859 г.) / А. В. Луночкин // Вопросы краеведения. Вып. 13 : материалы XXI и XXII краеведческих чтений. - Волгоград : Изд-во ВолГУ, 2012.C. $172-175$.

11. Непоспехов, О. О. Железнодорожное строительство и ростовское крестьянство в пореформенный период / О. О. Непоспехов // Труды Государственного исторического музея. Вып. 193. - М. : Государственный исторический музей, 2012. C. 224-235.

12. О вознаграждении за имущество, отходящее из частного владения в распоряжение правительства // Свод законов Российской империи. Изд. 1857. - СПб. : Тип. ІІ Отделения Собственной Е. И. В. Канцелярии, 1857. - Т. Х, ч. 1. -604 с.

13. О порядке отчуждения земель, входящих в состав выкупленных крестьянских угодий, под полосы железных дорог. 5 мая 1867 г. // ПСЗРИ. Собр. 2-е. - Т. 42, ч. 1. - № 44521.

14. О продлении действий временных правил по отчуждению частных имуществ под железные дороги. 18 декабря 1881 г. // ПСЗРИ. Собр. 3-е. T. 1. - № 568 .

15. Об инструкции для отвода и оценки отходящих под железные дороги казенных земель. 9 декабря 1868 г. // ПСЗРИ. Собр. 2-е. - Т. 43, ч. 2. № 46536 .

16. Об отчуждении земель, входящих в состав надела государственных крестьян, под полосы железных дорог. 31 октября 1868 г. // ПСЗРИ. Собр. 2-е. Т. 43, ч. 2. -№ 46408.

17. Об отчуждении казенных земель под линии железных дорог // Дополнение к ПСЗРИ. - Т. 43, ч. 2. - № 46223a.

18. Об оценке для публичной продажи // Свод законов Российской империи. Изд. 1857. - СПб. : Тип. ІІ Отделения Собственной Е. И. В. Канцелярии, 1857 - Т. Х, ч. $2 .-525$ с.

19. Об установлении временных правил по отчуждению частных имуществ под железные дороги. 6 мая 1872 г. // ПСЗРИ. Собр. 2-е. - Т. 47, ч. 1. № 50823 .

20. Погребинский, В. М. Очерки истории финансов дореволюционной России / В. М. Погребинский. - М. : Мысль, 1954. - 250 с.

21. Поликарпов, В. В. Русская военно-промышленная политика. 1914-1917 гг. Государствен- ные задачи и частные интересы / В. В. Поликарпов. - М. : Центрполиграф, 2015. - 383 с.

22. Положение Главного комитета об устройстве сельского состояния о порядке отчуждения под железные дороги земель, находящихся в непосредственном распоряжении помещика, в пользовании крестьян или в составе крестьянского надела. 18 января 1862 г. // ПСЗРИ. Собр. 2-е. - Т. 37, ч. 1. № 37880 .

23. Положение о выкупе крестьянами, вышедшей из крепостной зависимости, их усадебной оседлости, и содействии правительства к приобретению семи крестьянами в собственность полевых угодий от 19 февраля 1861 г. // ПСЗРИ. Собр. 2-е. - Т. 36, ч. 1. - № 36659 .

24. Соловьева, А. М. Железнодорожный транспорт в России во второй половине XIX века / А. М. Соловьева. - М. : Мысль, 1975. - 319 с.

\section{REFERENCES}

1. Vulfov A.B. Povsednevnaya zhizn rossiyskikh zheleznykh dorog [Everyday Life of Russian Railways]. Moscow, Molodaya gvardiya Publ., 2007. 496 p.

2. Vysochayshe utverzhdennoe polozhenie ob uchrezhdenii obshchestva aktsionerov dlya sooruzheniya zheleznoy dorogi ot Sankt-Peterburga do Tsarskogo sela, s prodolzheniem do Pavlovska. 21 marta $1836 \mathrm{~g}$. [The Highly Approved Provision on the Establishment of a Stock Company for the Construction of the Railway between Saint Petersburg and the Tsar's Village (Tsarskoe Selo), with the Extension up to Pavlovsk]. Polnoe sobranie zakonov Rossiyskoy imperii. Sobr. 2 [Complete Collection of Laws of the Russian Empire. 2nd Collection], 1836, vol. 11, no. 9009.

3. Galaktionova L.V. Pravovoe regulirovanie pozemelnykh otnosheniy na zheleznodorozhnom transporte $v$ Rossiyskoy imperii (1836-1917) [The Legal Regulation of Land Relations on the Railway Transport in the Russian Empire (1836-1917)]. Khabarovsk, Izd-vo Dalnevostoch. gos. un-ta putey soobshcheniya, 2009. $151 \mathrm{p}$.

4. General-prokurorskiy nakaz pri komissii o sostavlenii proekta novogo Ulozheniya, po kotoromu i marshalu postupat. 30 iyulya $1767 \mathrm{~g}$. [The General Prosecutor's Order at the Commission on Drawing up a Draft of the New Code, According to which the Marshal Must Act]. Polnoe sobranie zakonov Rossiyskoy imperii. Sobr. 2 [Complete Collection of Laws of the Russian Empire. $1^{\text {st }}$ Collection], 1767, vol. 18 , no. 12950 .

5. Gindin I.F. Gosudarstvennyy bank $i$ ekonomicheskaya politika tsarskogo pravitelstva (1861-1892) [The State Bank and Economic Policy 
of the Tsarist Government (1861-1892)]. Moscow, Gosfinizdat Pupl., 1960. 415 p.

6. Delo o voznagrazhdenii krestyan, sobstvennikov derevni Lagi za zemlyu, otoshedshuyu pod Moskovsko-Smolenskuyu zheleznuyu dorogu. 12 dekabrya 1970 po 16 dekabrya 1883 goda [The Case on the Compensation of Peasants, Owners of the Village Lagi, for the Land Alienated for the Construction of the Moscow-Smolensk Railway]. Rossiyskiy gosudarstvennyy istoricheskiy arkhiv [The Russian State Historical Archive], F. 229, Op. 7, D. 4, 111 L.

7. Delo o voznagrazhdenii statskogo sovetnika Shablykina i g. Ananyevskikh za zemli, otchuzhdaemye pod Orlovsko-Moskovskuyu zheleznuyu dorogu. 1868-1884 gg. [The Case on the Remuneration of the State Councilor Shablykin and Mr. Ananievky for the Lands Alienated to the Orel-Moscow Railway]. Rossiyskiy gosudarstvennyy istoricheskiy arkhiv [The Russian State Historical Archive], F. 229, Op. 7, D. 1. 51 L.

8. Dobbin F. Formirovanie promyshlennoy politiki: Soedinennye shtaty Ameriki, Velikobritaniya i Frantsiya v period stanovleniya zheleznodorozhnoy otrasli [Forging Industrial Policy: The United States, Britain, and France in the Railway Age]. Moscow, Higher School of Economics Publ., 2013. 368 p.

9. Kislinskiy N.A. Nasha zheleznodorozhnaya politika po dokumentam Komiteta Ministrov [Our Railway Policy according to the Documents of the Committee of Ministers]. Saint Petersburg, Izdanie kantselyarii Komiteta ministrov, 1902, vol. 1. 324 p.

10. Lunochkin A.V. Problema otchuzhdeniya zemli pri stroitelstve Volgo-Donskoy zheleznoy dorogi (1859 g.) [The Problem of Alienation of Land for the Volda-Don Railway Road]. Voprosy kraevedeniya. Vyp. 13: materialy XXI i XXII kraevedcheskikh chteniy [The Questions of Local History. Iss. 13. Proceedings of the $21^{\text {st }}$ and $22^{\text {nd }}$ Local History Readings]. Volgograd, Izd-vo VolGU, 2012, pp. 172-175.

11. Nepospekhov O.O. Zheleznodorozhnoe stroitelstvo i rostovskoe krestyanstvo v poreformennyy period [The Railway Construction and Rostov Peasants in the Post-reform Period]. Trudy Gosudarstvennogo istoricheskogo muzeya. Vyp. 193 [Works of The State Historical Museum. Iss. 193], Moscow, State Historical Museum, 2012, pp. 224-235.

12. O voznagrazhdenii za imushchestvo, otkhodyashchee iz chastnogo vladeniya v rasporyazhenie pravitelstva [On the Compensation for the Property Transferred from Private Ownership to the State]. Svod zakonov Rossiyskoy imperii. Izd. 1857 [The Code of Laws of the Russian Empire. Edition of 1857]. Saint Petersburg, Tip. II Otdeleniya Sobstvennoy E. I. V. Kantselyarii Publ., 1857. 604 p.

13. O poryadke otchuzhdeniya zemel, vkhodyashchikh v sostav vykuplennykh krestyanskikh ugodiy, pod polosy zheleznykh dorog. 5 maya 1867 g.
[On the Order of Alienation of the Lands that are the Part of Peasant Real Estate for Railways Construction]. Polnoe sobranie zakonov Rossiyskoy imperii. Sobr. 2 [Complete Collection of Laws of the Russian Empire. 2nd Collection], 1867, vol. 42, part 1, no. 44521.

14. O prodlenii deystviy vremennykh pravil po otchuzhdeniyu chastnykh imushchestv pod zheleznye dorogi. 18 dekabrya $1881 \mathrm{~g}$. [On the Renewal of the Temporary Rules on the Alienation of Private Property for Railways Construction]. Polnoe sobranie zakonov Rossiyskoy imperii. Sobr. 3 [Complete Collection of Laws of the Russian Empire. 3rd Collection], 1881, vol. 1, no. 568.

15. Ob instruktsii dlya otvoda i otsenki otkhodyashchikh pod zheleznye dorogi kazennykh zemel. 9 dekabrya $1868 \mathrm{~g}$. [On the Instructions for Valuation and the Alienation of Public Lands for Railways Construction]. Polnoe sobranie zakonov Rossiyskoy imperii. Sobr. 2 [Complete Collection of Laws of the Russian Empire. 2nd Collection], 1868, vol. 43, part 2, no. 46536.

16. Ob otchuzhdenii zemel, vkhodyashchikh $\mathrm{v}$ sostav nadela gosudarstvennykh krestyan, pod polosy zheleznykh dorog. 31 oktyabrya $1868 \mathrm{~g}$. [On the Alienation of Lands that are the Allotment of State Peasants for Railways Construction]. Polnoe sobranie zakonov Rossiyskoy imperii. Sobr. 2 [Complete Collection of Laws of the Russian Empire. 2nd Collection], 1868, vol. 43, part 2, no. 46408 .

17. Ob otchuzhdenii kazennykh zemel pod linii zheleznykh dorog [On the Alienation of State Lands for Railways Construction]. Dopolnenie k Polnomy Sobraniy Zakonov Rossiyskoy imperii [Addition to Complete Collection of Laws of the Russian Empire], 1868 , vol. 43, part 2, no. 46223a.

18. Ob otsenke dlya publichnoy prodazhi [Valuation for Public Sale]. Svod zakonov Rossiyskoy imperii. Izd. 1857 [The Code of Laws of the Russian Empire. Edition of 1857]. Saint Petersburg, Tip. II Otdeleniya Sobstvennoy E. I. V. Kantselyarii Publ., 1857, vol. 10, part $2.525 \mathrm{p}$.

19. Ob ustanovlenii vremennykh pravil po otchuzhdeniyu chastnykh imushchestv pod zheleznye dorogi. 6 maya 1872 g. [About Temporary Rules on Alienation of Private Property for Railways Construction]. Polnoe sobranie zakonov Rossiyskoy imperii. Sobr. 2 [Complete Collection of Laws of the Russian Empire. 2nd Collection], 1872, vol. 47, part 2, no. 50823.

20. Pogrebinskiy V.M. Ocherki istorii finansov dorevolyutsionnoy Rossii [The Essays on the History of the Finance of the Per-revolutionary Russian]. Moscow, Mysl Publ., 1954. 250 p.

21. Polikarpov V.V. Russkaya voennopromyshlennaya politika. 1914-1917 gg. Gosudarstvennye zadachi i chastnye interesy [Russain Military-Industrial Policy. 1914-1917. The 
State Objectives and Private Interests]. Moscow, TsentrpoligrafPubl., 2015. 383 p.

22. Polozhenie Glavnogo komiteta ob ustroystve selskogo sostoyaniya o poryadke otchuzhdeniya pod zheleznye dorogi zemel, nakhodyashchikhsya $\mathrm{v}$ neposredstvennom rasporyazhenii pomeshchika, $\mathrm{v}$ polzovanii krestyan ili v sostave krestyanskogo nadela. 18 yanvarya $1862 \mathrm{~g}$. [Provision of the Central Committee on the Organization of the Rural Estate, on the Order of Alienation of Lands that are in the Direct Possession of Landowner, in the Use of Peasants or in the Part of Peasants Allotment, for Railways Construction]. Polnoe sobranie zakonov Rossiyskoy imperii. Sobr. 2 [Complete Collection of Laws of the Russian Empire. 2nd Collection], 1862, vol. 37, part 1, no. 37880.
23. Polozhenie o vykupe krestyanami, vyshedshey iz krepostnoy zavisimosti, ikh usadebnoy osedlosti, i sodeystvii pravitelstva $\mathrm{k}$ priobreteniyu semi krestyanami v sobstvennost polevykh ugodiy ot 19 fevralya 1861 g. [Provision on Released Peasants' Repayment of Their Farmsteads and the Government's Assistance to Peasants in the Matter of Buying Theirs Field Lands]. Polnoe sobranie zakonov Rossiyskoy imperii. Sobr. 2 [Complete Collection of Laws of the Russian Empire. 2nd Collection], 1861, vol. 36, part 1, no. 36659 .

24. Solovyeva A.M. Zheleznodorozhnyy transport $v$ Rossii vo vtoroy polovine XIX veka [The Railway Transport in Russia in the Second Half of the $19^{\text {th }}$ Century]. Moscow, Mysl Publ., 1975. 319 p.

\section{Information about the Author}

Elena I. Nazarova, Postgraduate Student, Institute of History, Saint Petersburg State University; Teacher of History and Social Studies, School No. 123, Vyborg District of Saint Petersburg, Aleksandra Matrosova St., 11A, 194100 Saint Petersburg, Russian Federation, mrs.helnaz@gmail.com, https://orcid. org/0000-0002-1899-909X

\section{Информация об авторе}

Елена Игоревна Назарова, аспирант, Институт истории, Санкт-Петербургский государственный университет; учитель истории и обществознания, ГБОУ школа № 123 Выборгского района г. Санкт-Петербурга, ул. Александра Матросова, 11А, 194100 г. Санкт-Петербург, Российская Федерация, mrs.helnaz@gmail.com, https://orcid.org/0000-0002-1899-909X 